\title{
The socio-economic effects of Karun 3 dam on the sustainable development of rural areas. A case study in Iran
}

\section{Hojat Allah Sadeghi ${ }^{a}$, Seyed skandar Seidaiy*, Mohammad Reza Rezvani ${ }^{\text {b }}$}

\author{
a University of Isfahan, Iran \\ $b$ University of Tehran, Iran
}

\begin{abstract}
Aiming to explain the socio-economic effects of reservoir dams on the sustainable development of rural areas, this paper, as a case study on Iran focuses on Karun 3 Dam, the largest arch dam of the Middle East. 350 rural household were studied through survey data collection. The households settled in 38 villages where questionnaires were distributed accordingly. The results showed that the dam has been effective in improving agriculture and boosting local economic indices, but has not affected on tourism, industrial development and employment. Also, it seems that the indices of quality of life, welfare and social capital correlate with inefficient dam performance in rural sustainable economic development. Evaluation of the effective social and economic variables of the dam in relation to the sustainable development of rural settlements shows that there is a duality in management based sustainable development that has prevented the positive effects of the dam on villages.
\end{abstract}

Key Words: Dam effects, rural areas, sustainable development, Karun 3 Dam, Iran.

Article Info: Received: December 7, 2016; Final revision: October 14, 2017; Accepted: November 15, 2017; Online: November 25, 2017.

\section{Introduction}

The idea of sustainable development was proposed in 1972. More than one hundred definitions of sustainable development have been presented ever since.

* Corresponding author

Address: Faculty of Geographical Sciences and Planning, University of Isfahan, Isfahan City, Iran.

Phone: + 989166904491 | Email: s.seidiy@geo.ui.ac.ir

(C)2017 Human Geographies; The authors

(c) (1) This work is licensed under a

Creative Commons Attribution 4.0 International License. DOI:10.5719/hgeo.2017.112.6 
However, the most widely and influentially-accepted definition of sustainable development is that of the UN World Commission on Environment and Development in its 1987 report on "Our Common Future": 'development that meets the needs of the present without compromising the ability of future generations to meet their own needs'(QU et al., 2015).

In sustainable development, attention to environmental capacity and its proper use is highly important. Given the limited water resources, increased urban and rural population, the tendency to urbanisation, urban development, new town formations, industrial development and expansion of agricultural lands of villages, water planning should be taken into consideration from different angles (Shayan, 2010). Precipitation reduction, population growth and the importance of supplying food for the growing populations together with the special geographical situation of Iran led the authorities of the country to pay more attention to surface water control than before and put dam building on the agenda as a strategic factor (Rahmati \& Nazareian, 2011). In fact, most of the developed countries have presented and executed numerous water resource development projects to accelerate economic and social development. Moreover, dams are regarded as one of the important structures for water transfer and resource systems, Examples of these countries include China (Three Gorges Dam), South Korea (Andong Dam) and India (Srisailam Dam) (Pirestani \& Shafaghti, 2009), (Ishida et al., 2003). No doubt, these projects have had many positive and negative effects (Ghiami, 2011).

Considering the positive effects of dams on economy, especially agricultural economy, studies in the Netherlands showed that in some regions of this country, farmers needed to find more proper supplying methods for agricultural water in order to evaluate the effects of water management on agricultural land, determine the economic profitability, develop strategies and make practical decisions on water management (Devos et al., 2006). Furthermore, research on the High Aswan Dam in Egypt showed that the dam has led to agricultural and crop production growth, transportation boom and eventually a more dynamic rural population, in addition to controlling the water supply of the Lake Nasser (Strzepek et al., 2008).

Scudder (2012) studied different types of dams in various parts of the world and suggested that more than half of the dams, especially in Africa and Asia, have been developed for irrigation and agriculture purposes. He believes that such goals for dam construction have had many potentials and limitations, including agricultural boom, cropping pattern change, optimal use of water, rural migration, welfare needs of local communities, and flooding of lands (Scudder, 2012). Dam construction has social impacts, which may be positive or negative. Perceptions of the social impacts of dams are driven in large part by the scholarly literature that addresses those impacts (Kirchherr et al., 2016). They divide the social impacts of dams into three themes, including infrastructure (electricity, irrigation and water, flood control, roads and transportation), livelihood (land and housing, income and employment, health and nutrition) and community (social cohesion, cultural change, and resettlement). The dam can affect each of these positively or negatively. All of these are viewed through the dimensions of space, time, and value (Kirchherr \& J. Charles, 2016). In an econometric analysis, Strobl and O.Strobl )2011) showed that while downstream 
regions benefit from large dams, no beneficial effects accrue to croplands within the vicinity. Moreover, they found that the productivity impact of upstream dams depends on the local climate (Strobl \& O.Strobl, 2011). Duflo and Pandeh (2007) found that, in a district where a dam is built, agricultural production does not increase, but poverty does. Overall, their estimates show that the construction of large dams is a marginally cost-effective investment with significant distributional implications, and has resulted in increased poverty, on the whole (Dufl \& Pande, 2007).

The World Commission on Dams1 (2000)examined the effects of Pak Mun Dam(in Thailand), arguing that dams bring about social and political effects in addition to exerting economic impacts on their surrounding residents (WCD, 2000). Similarly, Campbell-Hyde (2013) showed that Three Gorges Dam (in China) has made the region environmentally more vulnerable, and has particularly increased farmland erosion and landslide rate. Local climate changes, as well as local conflicts, are seen as other consequences of constructing dams (Campbell-Hyde, 2013). Dams, therefore, as major economic and industrial projects at regional level, have different environmental-spatial effects on the sustainable development of the surrounding rural and urban areas in structuralfunctional terms (Rahamati, 2012) and affect the economic, social, cultural, environmental, and physical aspects of life in human settlements (Riahi, 2013). Tilt et al. (2009) investigated the socio-economic impacts of dams on migration and resettlement, changes in the rural economy, employment structure, infrastructure and housing, cultural aspects, health and health relations. They point out that the identification of potential effects of dams before construction can result in better decisions about future problems. Moreover, assessment of such impacts could help promote sustainable development strategies settlements (Tilt et al., 2009). Moreover, Egre and Senecal (2003) investigated the social impacts of dams in the past two decades settlements (Egred \& Senecal, 2003). Bhatia et al, (2008) evaluated the indirect economic effects of dams in India, Egypt and Brazil (Bhatia et al., 2008) and Huiyi (2013) studied dams with a focus on sustainable development and obtained similar conclusions in terms of the social, economic and development effects of dams (Huiyi, 2013).

With regard to these negative effects, some international organisations have conducted studies to stop water supply projects such as constructing dams in developing countries. Many scholars have also taken into account the cultural, social, economic and environmental development in water resource management (Tahmicooglu et al., 2007). The construction of dams has been discussed widely, according to World Commission on Dams(2000). Construction method and the socio-economic consequences of dams such as their effectiveness on surrounding communities and villages, the livelihood of the people and nearby area residents as well as ecosystems, have been proposed as global issues to international discussion circles (WCD, 2000). If management is efficient and optimal both before and after constructing a dam, many affective negative consequences can be regionally prevented, and the development process can be directed towards environmental sustainability (Sahdati et al., 2009). However, new issues and consequences would affect rural and urban areas if no such management and the systematic view are adopted at different levels. Rural development needs the vision to place positive effects on the rural economy and 
Social (Cuciureanu \& Latu, 2016). Therefore, Villages are directly bound to development plans that have certain effects on the social and economic lives of their inhabitants. Nowadays, attempts are made in the form of project development impact assessment to evaluate the advantages and disadvantages of development activities in each region (Malekhoseini \& Mirakzedeh, 2014).

Karun 3 Dam is the largest arch dam in the Middle East and one of the reservoir dams in Iran, constructed on the Karun River in Izeh county (Khuzestan province), southwest of Iran. The dam construction began in 1994 and finished in 2004. In fact, it took about 10 years to build and almost 12 years have passed since the start of the project. The power plant related to this dam is currently one of the largest hydroelectric power plants in Iran, with the annual electricity production of 4172 million $\mathrm{KWH}$.

The aim of construction of the dam and Karun 3 power plant was to provide part of the electricity needs, as well as to control destructive floods in Iran country. Since the operation of Karun 3 dam, over 8 flood occurrences with more than 2,000 cubic meters per second flow, including two floods with a flow rate of 6500 and 4300 cubic meters per second have been controlled by the dam (IWPCO, 2012)2. During construction, employment opportunities were created for over 22 thousand people (direct and indirect employment), many of whom were villagers. There were 63 small and big villages in the workshop area and Karun 3 lake, out of which 39 villages lost their belongings and the rest their (Jehad, 2002).

What is obvious as one of the main consequences of the dam is the displacement of the population of the surrounding rural areas. The population of villages downstream and upstream of the dam may move to the nearest urban locations or choose to settle in a new town. Nonetheless, in some cases, the whole village has been moved. Thus, population displacement and lack of planning for their settlement before the start of the project is known as one of the socio-economic problems in the region that has resulted in the irregular migration of hundreds of people over the past few years. The focus of previous studies, being qualitative by nature, has mostly been on the social, economic and environmental effects of dams. According to Kirchherr et al. (2016), more than 217 papers have been published from 1990 to 2015 on the social impacts of dams, among which 55 papers were theoretical; 58 percent were qualitative, 26 percent were quantitative, and 16 percent used mixed method (Kirchherr et al., 2016). As such, there is a scarcity of quantitative studies in this field. Furthermore, the previous investigations have studied the indices and consequences of dam construction, using a fixed framework. However, this research studies these effects through a quantitative method and drawing on a sustainable development framework. With respect to rare quantitative studies, this research tries to answer the following questions.

1. What are the effects of the dam in Socio-economic context on surrounding villages as to their status before and after dam construction?

2. Is there any significant difference between the three types of surrounding villages of the dam according to socio-economic variables?

3. What is the prioritisation concerning the created potentials as to sustainable development in rural areas? 


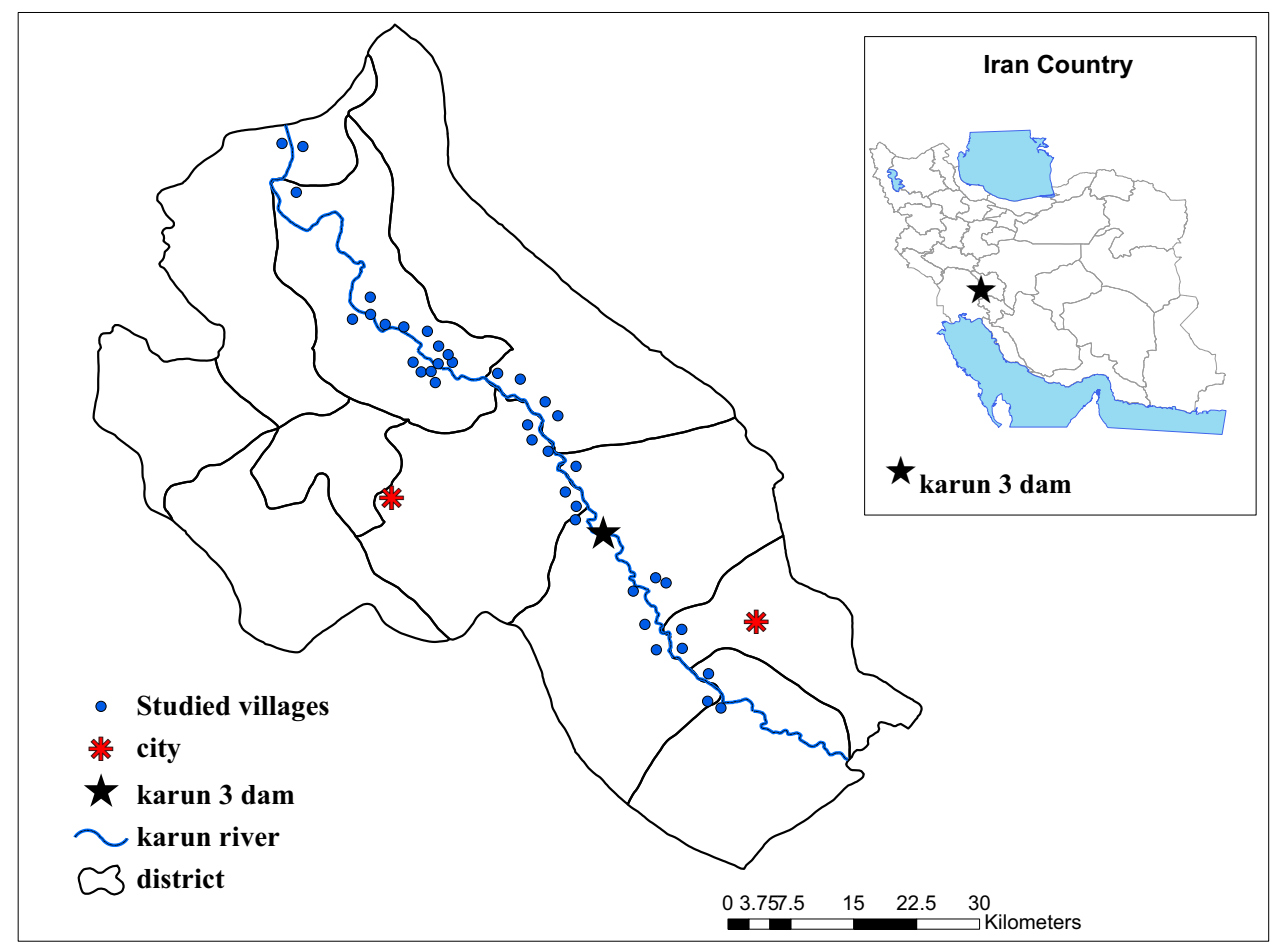

Figure 1. Geographical location of Villages in Izeh County (Authors, 2016)

\section{An introduction to the area study}

The study area, Izeh County, is located in Khuzestan province, southwest of Iran, in 31 degrees, 50' 22" northern hemisphere and 49 degrees, 52' 16" east of Prime Meridian. It is located on the hillsides of the Zagros Mountains with the height of 767 meters above sea level and covers an area of about 3779.39 square kilometres. (The given number belongs to the city of Izeh, where Karun 3 is located, and the villages under study cover an area over 486.42 square kilometres).Topographically, this region consists of plain and mountainous regions (Mikaniki \& Sadeghi, 2013). According to the Statistical Center of Iran, the rural population of the region was 95123 in 1996 . Also in 2006, the study area had 353 villages that total rural population reached over 86,197 villagers(Statistical Center of Iran, 2006). The 2011's statistics revealed that the population fell to 81,581 (a decrease by 4624 people over five years) after building the dam (Statistical Center of Iran, 2011). Therefore, investigation of the population changes in the region from 1996 to 2011 revealed an ongoing decrease of population in such a way that after the construction of the dam, this trend gained momentum, leading to the evacuation of most rural areas. Figure 1 show geographical location of villages in Izeh county and Iran country .

\section{Methodology}

This research is survey-questionnaire and based on the opinions of the rural people. Two main and control groups are villages, had been studied in this 
research. The main group of villages are in the dam vicinity, and the control group of villages are not in the dam vicinity. The main group includes 38 villages. These villages have 13011 people and 2,531 households (Statistical Center of Iran, 2011). Based on Cochran's formula (formula1), 334 households were calculated which were finally increased to 350 households to enhance accuracy and reliability. In the second group, the control group includes of 7 villages, and 150 people were studied in these villages. The control group was used to validate the results of economic and social variables the main group. Data were collected through questionnaire according to Likert scale, is very low (1) to very high (5). Term completing the questionnaires had lasted about 8 months. Data were collected and then entered into SPSS software. PairedSample T-Test, variance analysis (One Way ANOVA), One-Sample T-Test, and Duncan's Test were used to analyse the data.

In Cochran's formula ( $\mathrm{n}=$ sample size), $(\mathrm{Z}=$ standard normally distributed random variable that is 1.96$),(\mathrm{d}=$ confidence interval or the required precision at the level 0.05$),(\mathrm{N}=$ The size of the statistical population is 2531 households), $(\mathrm{p}=$ the estimated proportion of an attribute that is present in the population at 0.05 level) and $(q=$ a proportion of the population lacking a specific attribute at 0.05 level $(q=1-p)$.

$$
n=\frac{\frac{Z^{2} p q}{d^{2}}}{1+\frac{1}{N}\left(\frac{Z^{2} p q}{d^{2}}-1\right)}=\frac{\frac{1.96^{2} 0.5 * 0.5}{0.05^{2}}}{1+\frac{1}{2531}\left(\frac{1.96^{2} 0.5 * 0.5}{d^{2}}-1\right)}=334 \cong 350
$$

\section{Results}

\section{The effect of dam on the economic development of villages}

To compare the economic variable status in villages before and after dam construction is run Paired-Sample T-Test, that the data before the dam construction and then the data after the dam construction were applied. Concerning the Significant level for tourism development, employment and industry development indices which are $(\operatorname{sig}=0.000)$ and since the sig is less $(.000<0.05)$, Significant difference these indices confirmed with respect to both above mentioned two periods. Here in all indices, both the average volume and $t$ volume are positive. Hence, it is concluded that according to participants' opinion the mentioned three indices follow a negative trend in comparison with the period before the dam construction.

The Paired-Sample T-Test results indicate that agricultural development and local economy improvement indices $(.000<0.05)$, reveal a Significant difference for both periods. In addition, the negative $t$ volume and the average difference for both indices in the two periods (before and after the dam construction) are respectively -0.182 and -0.282 , here it is deduced that the existence of this dam has been positive with an effect on agricultural development and local improvement of economy. Moreover, the income index was in significant level $(\mathrm{Sig}=0.068)$ and since the sig is more $(.068>0.05)$. Therefore, the lack of a significant difference between the status of the income index before and after 
Table 1. Significant level of economic indices of rural areas in the main group

\begin{tabular}{|c|c|c|c|c|c|c|c|c|c|}
\hline \multirow{3}{*}{ Index } & \multirow{3}{*}{ period } & \multicolumn{5}{|c|}{ Paired Differences } & \multirow{3}{*}{$t$} & \multirow{3}{*}{$D f^{2}$} & \multirow{3}{*}{$\begin{array}{l}\mathrm{Sig}^{3}(2- \\
\text { tailed) }\end{array}$} \\
\hline & & \multirow[t]{2}{*}{ Mean } & \multirow[t]{2}{*}{ Std.Deviation ${ }^{1}$} & \multirow[t]{2}{*}{$\begin{array}{l}\text { Std. Error } \\
\text { Mean }\end{array}$} & \multicolumn{2}{|c|}{$\begin{array}{l}95 \% \text { confidence } \\
\text { Interval of the } \\
\text { Difference }\end{array}$} & & & \\
\hline & & & & & Lower & Upper & & & \\
\hline \multirow{2}{*}{$\begin{array}{l}\text { Agricultural } \\
\text { development }\end{array}$} & Before $^{4}$ & \multirow{2}{*}{$0 . \overline{182}$} & \multirow[b]{2}{*}{1.03} & \multirow[b]{2}{*}{0.055} & \multirow[b]{2}{*}{0.073} & \multirow[b]{2}{*}{0.291} & \multirow[b]{2}{*}{-3.29} & \multirow[b]{2}{*}{349} & \multirow[b]{2}{*}{0.001} \\
\hline & After & & & & & & & & \\
\hline \multirow{2}{*}{$\begin{array}{l}\text { Tourism } \\
\text { development }\end{array}$} & Before & \multirow{2}{*}{0.820} & \multirow{2}{*}{0.548} & \multirow{2}{*}{0.029} & \multirow{2}{*}{-0.878} & \multirow{2}{*}{-0.763} & \multirow{2}{*}{28.01} & \multirow{2}{*}{349} & \multirow{2}{*}{0.000} \\
\hline & After & & & & & & & & \\
\hline \multirow{2}{*}{ Employment } & Before & \multirow{2}{*}{0.442} & \multirow{2}{*}{0.686} & \multirow{2}{*}{0.036} & \multirow{2}{*}{-0.515} & \multirow{2}{*}{-0.370} & \multirow{2}{*}{12.07} & \multirow{2}{*}{349} & \multirow{2}{*}{0.000} \\
\hline & After & & & & & & & & \\
\hline Lnoา & Before & - & 0057 & 001 & דרני & $0 \cap 0$ & 100 & 210 & $00<0$ \\
\hline Income & After & 0.085 & 0.857 & 0.046 & $-0.11 / 7$ & 0.006 & -1.83 & 349 & 0.068 \\
\hline Industry & Before & דחי & 0 & $00 \Omega$ & 0.15 & 0050 & 1) & 240 & $0 \cap 0$ \\
\hline development & After & 0.107 & 0.450 & 0.024 & -0.124 & -0.059 & 4.44 & 344 & 0.000 \\
\hline & Before & & & & & & & & \\
\hline $\begin{array}{l}\text { the local } \\
\text { economy }\end{array}$ & After & $0 . \overline{282}$ & 1.01 & 0.054 & 0.176 & 0.388 & -5.23 & 349 & 0.000 \\
\hline
\end{tabular}

1. Std.Deviation(Standard Deviation) is one dispersion indicator that shows data how much distance has than average value.

2. $\operatorname{df}($ Degree of freedom): The number of independent observations minus the number of estimated parameters

3.Sig is abbreviation for significant that shows and measures the difference between variables through the significance level of less than 0.05 .

2.Std.Deviation(Standard Deviation) is one dispersion indicator that shows data how much distance has than average value.

4.. Before(Before dam construction) and After(After dam construction)

dam construction confirmed. Also, the t volume and the average difference for this index indicate that there is no difference between the income status of the villagers before and after the dam construction. In fact, the dam construction has not affected in the rural incomes (Table1).

Assessing the economic variable in the control group indicates that all six indices have a significant level $(.000>0.05)$.Consequently, lack of significant difference in this confirmed the six indices in the control group as to both the periods. By comparing the results obtained from the main and control groups, it is deduced that the economic indices of the main group are correct. Therefore, the status of each one of indices here is subject to the dam construction (Table 2).

\section{The effect of the Karun 3 Dam on the social development indicated of the villages studied}

As to the three indices of social capital, social welfare and life quality in villages, the assessment was run based on the participants' response to the questionnaire for before and after the dam construction. Social capital concerns the investigation of factors such as people's participation, reduced disputes, environmental 
Table 2. Significant level of economic indices of rural areas in the control

\begin{tabular}{|c|c|c|c|c|c|c|c|c|c|}
\hline \multirow{3}{*}{ Index } & \multirow{3}{*}{ period } & \multicolumn{5}{|c|}{ Paired Differences } & \multirow{3}{*}{$t$} & \multirow{3}{*}{$D f^{2}$} & \multirow{3}{*}{$\begin{array}{l}\mathrm{Sig}^{3}(2- \\
\text { tailed) }\end{array}$} \\
\hline & & \multirow{2}{*}{ Mean } & \multirow{2}{*}{ Std.Deviation' } & \multirow{2}{*}{$\begin{array}{l}\text { Std.Error } \\
\text { Mean }\end{array}$} & \multicolumn{2}{|c|}{$\begin{array}{l}95 \% \text { confidence Interval } \\
\text { of the Difference }\end{array}$} & & & \\
\hline & & & & & Lower & Upper & & & \\
\hline \multirow{2}{*}{$\begin{array}{l}\text { Agricultural } \\
\text { development }\end{array}$} & Before $^{4}$ & \multirow[b]{2}{*}{-0.045} & \multirow[b]{2}{*}{0.546} & \multirow[b]{2}{*}{0.055} & \multirow[b]{2}{*}{0.073} & \multirow[b]{2}{*}{0.291} & \multirow[b]{2}{*}{-0.29} & \multirow[b]{2}{*}{149} & \multirow[b]{2}{*}{0.078} \\
\hline & After & & & & & & & & \\
\hline \multirow{2}{*}{$\begin{array}{l}\text { Tourism } \\
\text { development }\end{array}$} & Before & \multirow{2}{*}{-0.084} & \multirow{2}{*}{0.999} & \multirow{2}{*}{0.053} & \multirow{2}{*}{-0.190} & \multirow{2}{*}{0.019} & \multirow{2}{*}{-1.60} & \multirow{2}{*}{149} & \multirow{2}{*}{0.110} \\
\hline & After & & & & & & & & \\
\hline \multirow{2}{*}{ Employment } & Before & \multirow{2}{*}{-0.043} & \multirow{2}{*}{0.874} & \multirow{2}{*}{0.041} & \multirow{2}{*}{-0.154} & \multirow{2}{*}{0.023} & \multirow{2}{*}{-1.32} & \multirow{2}{*}{149} & \multirow{2}{*}{0.084} \\
\hline & After & & & & & & & & \\
\hline Incrmo & Before & 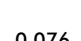 & 0654 & 0051 & 0132 & 0025 & 087 & 140 & ברית \\
\hline income & After & $-0.0 / 0$ & 0.054 & 0.051 & -0.132 & 0.020 & -0.01 & 149 & 0.001 \\
\hline Industry & Before & & & & & & & & \\
\hline development & After & -0.040 & 0.041 & 0.001 & -0.100 & 0.020 & -1.72 & 147 & דו \\
\hline & Before & & & & & & & & \\
\hline $\begin{array}{l}\text { the local } \\
\text { economy }\end{array}$ & After & -0.071 & 0.456 & 0.051 & -0.065 & 0.018 & -1.25 & 149 & 0.089 \\
\hline
\end{tabular}

responsibility and interaction between people. Social welfare entailed the study of factors such as income and wealth increase, poverty reduction, equitable resources distribution and security. Finally, life quality focused on factors like dietary variety, mental health level, physical health level and crime reduction; Because each of these indices can be changed by the dam construction (Malekhoseini \& Mirakzedeh,2014). The Paired-Sample T-Test results indicate that social capital, social welfare and life quality indices with respect to significant level $(\operatorname{sig}=0.000)$ and since their sig is less $(.000<0.05)$; Therefore, This status reveals a Significant difference about three indices for both periods. Also, in all social indices, both the average volume and t volume are positive. Hence, it is deduced that according to participants' opinion the mentioned three indices follow a negative trend in comparison with the period before the dam construction (Table 3) because the data before the dam construction and then the data after the dam construction ware applied in paired-sample T-Test.

Assessing the social variable in the control group indicates that all three indices have a significant level $(.000>0.05)$. Consequently, lack of significant difference in this variable confirmed the three indices in the control group as to both the periods. By comparing the results obtained from the main and control groups, it is deduced that the social indices of the main group are correct. Therefore, the status of each one of the indices here is subject to the dam construction (Table 4).

Comparison of the effects of dam based on the geographical position of rural areas

After the influence of the constructed dam on the socio-economic variables is assessed, the three types of rural areas surrounding the dam are assessed. Each 
Table 3. Significant level of social indices of rural areas in the main group

\begin{tabular}{|c|c|c|c|c|c|c|c|c|c|}
\hline \multirow{3}{*}{ Index } & \multirow{3}{*}{ period } & \multicolumn{5}{|c|}{ Paired Differences } & \multirow{3}{*}{$t$} & \multirow{3}{*}{ df } & \multirow{3}{*}{$\begin{array}{l}\text { Sig' }^{\prime}(2- \\
\text { tailed) }\end{array}$} \\
\hline & & \multirow[t]{2}{*}{ Mean } & \multirow[t]{2}{*}{ Std.Deviation ${ }^{2}$} & \multirow[t]{2}{*}{$\begin{array}{c}\text { Std.Error } \\
\text { Mean }\end{array}$} & \multicolumn{2}{|c|}{$\begin{array}{c}95 \% \\
\text { confidence } \\
\text { Interval of the } \\
\text { Difference }\end{array}$} & & & \\
\hline & & & & & Lower & Upper & & & \\
\hline \multirow{2}{*}{$\begin{array}{l}\text { Social } \\
\text { capital }\end{array}$} & Before $^{3 *}$ & \multirow{2}{*}{0.9957} & \multirow{2}{*}{0.545} & \multirow{2}{*}{0.029} & \multirow{2}{*}{0.938} & \multirow{2}{*}{1.053} & \multirow{2}{*}{34.14} & \multirow{2}{*}{349} & \multirow{2}{*}{0.000} \\
\hline & After & & & & & & & & \\
\hline \multirow{2}{*}{$\begin{array}{l}\text { Social } \\
\text { welfare }\end{array}$} & Before & \multirow{2}{*}{0.415} & \multirow{2}{*}{0.434} & \multirow{2}{*}{0.023} & \multirow{2}{*}{0.369} & \multirow{2}{*}{0.460} & \multirow{2}{*}{17.84} & \multirow{2}{*}{349} & \multirow{2}{*}{0.000} \\
\hline & After & & & & & & & & \\
\hline \multirow{2}{*}{$\begin{array}{l}\text { Quality of } \\
\text { life }\end{array}$} & Before & \multirow{2}{*}{0.628} & \multirow{2}{*}{0.557} & \multirow{2}{*}{0.029} & \multirow{2}{*}{0.570} & \multirow{2}{*}{0.687} & \multirow{2}{*}{21.10} & \multirow{2}{*}{349} & \multirow{2}{*}{0.000} \\
\hline & After & & & & & & & & \\
\hline
\end{tabular}

1.Sig is abbreviation for significant that shows and measures the difference between variables through the significance level of less than 0.05 .

2. Std.Deviation(Standard Deviation) is one dispersion indicator that shows data how much distance has than average value.

3. Before(Before dam construction) and After(After dam construction)

Table 4. Significant level of social indices of rural areas in the control group

\begin{tabular}{|c|c|c|c|c|c|c|c|c|c|}
\hline \multirow{3}{*}{ Index } & \multirow{3}{*}{ period } & \multicolumn{5}{|c|}{ Paired Differences } & \multirow{3}{*}{$t$} & \multirow{3}{*}{$d f$} & \multirow{3}{*}{$\begin{array}{l}\mathrm{Sig}^{\prime}(2- \\
\text { tailed) }\end{array}$} \\
\hline & & \multirow[t]{2}{*}{ Mean } & \multirow[t]{2}{*}{ Std.Deviation ${ }^{2}$} & \multirow{2}{*}{$\begin{array}{l}\text { Std. Error } \\
\text { Mean }\end{array}$} & \multicolumn{2}{|c|}{$\begin{array}{l}95 \% \text { confidence } \\
\text { Interval of the } \\
\text { Difference }\end{array}$} & & & \\
\hline & & & & & Lower & Upper & & & \\
\hline \multirow{2}{*}{ Social capital } & Before $^{3 *}$ & \multirow{2}{*}{-0.051} & \multirow{2}{*}{0.432} & \multirow{2}{*}{0.056} & \multirow{2}{*}{-0.128} & \multirow{2}{*}{0.031} & \multirow{2}{*}{-0.64} & \multirow{2}{*}{149} & \multirow{2}{*}{0.080} \\
\hline & After & & & & & & & & \\
\hline \multirow{2}{*}{$\begin{array}{l}\text { Social } \\
\text { welfare }\end{array}$} & Before & \multirow{2}{*}{-0.056} & \multirow{2}{*}{0.521} & \multirow{2}{*}{0.064} & \multirow{2}{*}{-0.131} & \multirow{2}{*}{0.030} & \multirow{2}{*}{-1.19} & \multirow{2}{*}{149} & \multirow{2}{*}{0.072} \\
\hline & After & & & & & & & & \\
\hline Quality of life & Before & -0.073 & 0.548 & 0.062 & -0.127 & 0.037 & -1.41 & 149 & 0.091 \\
\hline
\end{tabular}

one of these three types could have been affected differently by the mentioned indices after dam construction. These three types of rural areas are villages without change, displaced villages and land-ownership only villages. Analysis of variance (One-way ANOVA) was used to examine the significant differences of dam effects on the economic and social variables among the three types of rural areas. With respect to the results, it is deduced that the effects of the dam on three types of rural areas regarding all the socio-economic indices have been significantly different except for agricultural development $(.000<0.05)$. Hence, these significant differences in three types of rural areas might not have occurred on a casual basis, and Independent variable (Dam) has been an effect on the dependent variable (economic and social variables). In addition, this means that at least one of these three types of rural areas is different from others regarding the dam effects. The overall conclusion is that there is a significant difference among the three types of rural areas in terms of the difference in effects. Only in the about agricultural development index, there was no significant difference among the three types of rural areas regarding the difference in effects (Table 5). 
Table 5. Significant difference of indices in terms of the types of rural areas

\begin{tabular}{|c|c|c|c|c|c|c|}
\hline Index & Variance & $\begin{array}{l}\text { Sum of } \\
\text { Squares }\end{array}$ & $D f^{1}$ & $\begin{array}{l}\text { Mean } \\
\text { Square }\end{array}$ & $\mathrm{F}^{2}$ & $\mathrm{Sig}^{3}$ \\
\hline \multirow{3}{*}{$\begin{array}{l}\text { Agricultural } \\
\text { development }\end{array}$} & Between & 2.88 & 2 & 1.44 & \multirow{3}{*}{2.293} & \multirow{3}{*}{0.102} \\
\hline & Wifhips & 217.8 & 347 & 0.628 & & \\
\hline & foroups & 220.7 & 349 & *** & & \\
\hline \multirow{3}{*}{$\begin{array}{l}\text { Tourism } \\
\text { development }\end{array}$} & Between & 10.48 & 2 & 5.24 & \multirow{3}{*}{29.788} & \multirow{3}{*}{0.000} \\
\hline & Wifhups & 61.07 & 347 & 0.176 & & \\
\hline & forofps & 71.56 & 349 & $* * *$ & & \\
\hline \multirow[t]{3}{*}{ Employment } & Between & 27.25 & 2 & 13.62 & \multirow{3}{*}{183.929} & \multirow{3}{*}{0.000} \\
\hline & Wifhups & 25.71 & 347 & 0.074 & & \\
\hline & forolps & 52.96 & 349 & $* * *$ & & \\
\hline \multirow[t]{3}{*}{ Income } & Between & 16.70 & 2 & 8.35 & \multirow{3}{*}{29.281} & \multirow{3}{*}{0.000} \\
\hline & Wifhups & 99.00 & 347 & 0.285 & & \\
\hline & foralps & 115.7 & 349 & $* * *$ & & \\
\hline \multirow{3}{*}{$\begin{array}{l}\text { Industry } \\
\text { development }\end{array}$} & Between & 55.01 & 2 & 27.50 & \multirow{3}{*}{109.768} & \multirow{3}{*}{0.000} \\
\hline & Wifuins & 86.95 & 347 & 0.251 & & \\
\hline & fotalps & 141.9 & 349 & $* * *$ & & \\
\hline \multirow{3}{*}{$\begin{array}{l}\text { Strengthening } \\
\text { the local } \\
\text { economy }\end{array}$} & Between & 8.51 & 2 & 4.26 & \multirow{3}{*}{10.819} & \multirow{3}{*}{0.000} \\
\hline & Wifhips & 112.6 & 347 & 0.325 & & \\
\hline & Forgatps & 121.1 & 349 & $* * *$ & & \\
\hline \multirow[t]{3}{*}{ Social capital } & Between & 12.4 & 2 & 6.02 & \multirow{3}{*}{175.74} & \multirow{3}{*}{0.000} \\
\hline & Wifhips & 11.8 & 347 & 0.034 & & \\
\hline & foroups & 23.9 & 349 & $* * *$ & & \\
\hline \multirow[t]{3}{*}{ Social welfare } & Between & 41.9 & 2 & 20.95 & \multirow{3}{*}{176.17} & \multirow{3}{*}{0.000} \\
\hline & Wifups & 41.2 & 347 & 0.119 & & \\
\hline & Foroups & 83.1 & 349 & $* * *$ & & \\
\hline \multirow[t]{3}{*}{ Quality of life } & Between & 17.6 & 2 & 8.80 & \multirow{3}{*}{135.37} & \multirow{3}{*}{0.000} \\
\hline & Wifhips & 22.5 & 347 & 0.065 & & \\
\hline & Total & 40.1 & 349 & $* * *$ & & \\
\hline
\end{tabular}

1. $d f($ Degree of freedom): The number of independent observations minus the number of estimated parameters.

2. $F$ is abbreviation for F Fisher Test that whatever be larger, the more probably is a significant difference.

3.Sig is abbreviation for significant that shows and measures the difference between variables through the significance level of less than 0.05 .

To determine the differences among the three types of rural areas, regarding dam effectiveness in the significant economic and social variables, Duncan test was used. The results of the Duncan test showed that, regarding the tourism development index, the type of villages without change with an average of (3.85) has a significant difference with two other rural type. Also, In terms of employment index, the unchanged villages with the average (3.90), In terms of income index, the displaced villages with average of (3.45), In terms of industrial development, the unchanged villages with average of (3.20) and in terms of improvement of local economy, the displaced villages with average of (3.01) has a significant difference with two other rural type. Therefore, each one of the 
Table 6. The classification of the types of rural areas in homogeneous groups based on significant level of indices in terms of dam effects

\begin{tabular}{|c|c|c|c|c|c|}
\hline \multirow{2}{*}{$\begin{array}{l}\text { Indices and the types of rural areas(villages) } \\
\text { Tourism development }\end{array}$} & \multicolumn{2}{|c|}{$\begin{array}{c}\text { Subset for } \\
\text { alpha }=0.05\end{array}$} & \multirow{2}{*}{\begin{tabular}{|l|}
$\begin{array}{l}\text { Indices and the types of } \\
\text { rural areas(villages) }\end{array}$ \\
Employment
\end{tabular}} & \multicolumn{2}{|c|}{$\begin{array}{c}\text { Subset for } \\
\text { alpha }=0.05\end{array}$} \\
\hline & $N^{1}$ & mean & & $\mathrm{N}$ & mean \\
\hline Displaced Villages (margin of lake) & 125 & 3.18 & $\begin{array}{l}\text { land-ownership-only } \\
\text { village }\end{array}$ & 91 & 3.19 \\
\hline Land-ownership-only villages & 91 & 3.36 & $\begin{array}{l}\text { Displaced village (margin } \\
\text { of lake) }\end{array}$ & 125 & 3.63 \\
\hline Unchanged village & 134 & 3.58 & Unchanged village & 134 & 3.90 \\
\hline Income & $\mathrm{N}$ & mean & Industry development & $\mathrm{N}$ & mean \\
\hline Unchanged village & 134 & 3.00 & $\begin{array}{l}\text { Displaced village (margin } \\
\text { of lake) }\end{array}$ & 125 & 2.34 \\
\hline Land-ownership-only villages & 91 & 3.00 & $\begin{array}{l}\text { Land ownership-only } \\
\text { village }\end{array}$ & 91 & 3.09 \\
\hline Displaced village (margin of lake) & 125 & 3.45 & Unchanged village & 134 & 3.20 \\
\hline Strengthening local economy & $\mathrm{N}$ & mean & Social capital & $\mathrm{N}$ & mean \\
\hline Land-ownership-only village & 91 & 2.68 & unchanged village & 134 & 1.88 \\
\hline Unchanged village & 134 & 2.69 & Displaced village (lake) & 125 & 2.11 \\
\hline Displaced village (margin of lake) & 125 & 3.01 & $\begin{array}{l}\text { Land-ownership-only } \\
\text { village }\end{array}$ & 91 & 2.34 \\
\hline Social welfare & $\mathrm{N}$ & mean & Quality of life & $\mathrm{N}$ & mean \\
\hline Unchanged village & 134 & 2.13 & $\begin{array}{l}\text { Land-ownership-only } \\
\text { village }\end{array}$ & 91 & 2.39 \\
\hline Changed village (margin of lake) & 125 & 2.72 & $\begin{array}{l}\text { Displaced Village (margin } \\
\text { of lake) }\end{array}$ & 125 & 2.68 \\
\hline Land-ownership-only village & 91 & 2.94 & Unchanged village & 134 & 2.96 \\
\hline
\end{tabular}

$1 . \mathrm{N}$ is abbreviation for Number that shows or expresses frequency or the Number of responses for each group of villages.

three types of rural areas, based on geographical location and connection with the dam, has accepted a different effect from Karun 3 Dam according to economic variables. Also, For the social variable, social capital and social welfare indices with the average 2.34 and 2.94 respectively were the highest difference in land-ownership-only villages, while in terms of life quality, the unchanged villages with the average 2.96 showed the highest difference compared to the other two types. According to the level of differences, it is worth noting that although there were differences between villages in terms of social capital, social welfare and life quality indices, the dam had a little unclear effect on the development of these indices (Table 6).

\section{Prioritization potentials for sustainable rural development}

In order to apply potentials developed by the dam construction with respect to the sustainable development of the rural areas more in-depth assessment is 
Table 7. Development priorities for the sustainability of rural areas after dam construction and their significant level

\begin{tabular}{|c|c|c|c|c|c|c|c|}
\hline \multirow{3}{*}{ Index } & \multicolumn{7}{|c|}{ Test Value $=3$} \\
\hline & \multirow{2}{*}{ Mean } & \multirow{2}{*}{$t$} & \multirow{2}{*}{$D f^{\prime}$} & \multirow{2}{*}{$\mathrm{Sig}^{2}$ (2-tailed) } & \multirow{2}{*}{$\begin{array}{c}\text { Mean } \\
\text { Difference }\end{array}$} & \multicolumn{2}{|c|}{$\begin{array}{l}95 \% \text { confidence Interval } \\
\text { of the Difference }\end{array}$} \\
\hline & & & & & & Lower & Upper \\
\hline Farming & 4.22 & 25.6 & 349 & 0.000 & 1.22 & 1.13 & 1.32 \\
\hline Horticulture & 3.93 & 15 & 349 & 0.000 & 0.93 & 0.80 & 1.05 \\
\hline Animal husbandry & 3.09 & 2.01 & 349 & 0.045 & 0.97 & 0.002 & 0.19 \\
\hline Fishery & 3.45 & 9.6 & 349 & 0.000 & 0.45 & 0.36 & 0.54 \\
\hline Tourism & 4.35 & 33.5 & 349 & 0.000 & 1.35 & 1.27 & 1.43 \\
\hline Services & 3.10 & 2.1 & 349 & 0.029 & 0.10 & 0.01 & 0.19 \\
\hline Handicrafts & 2.82 & -4.4 & 349 & 0.000 & -0.17 & -0.25 & -0.09 \\
\hline $\begin{array}{l}\text { Workshops } \\
\text { industry }\end{array}$ & 2.92 & -2.1 & 349 & 0.031 & -0.08 & -0.15 & -0.007 \\
\hline
\end{tabular}

1. $d f(D e g r e e$ of freedom): The number of independent observations minus the number of estimated parameters. 2.Sig is abbreviation for significant that shows and measures the difference between variables through the significance level of less than 0.05 .

necessary. Considering the studies on sustainability in rural areas and living standards developments, there are eight potentials in rural areas, which with respect to dam effects; it is possible to develop them. These indices are farming, horticulture, animal husbandry, fisheries, tourism, services, handicrafts and workshop industries. The one-sample t-test was used to determine the extent to which each dam-driven development priority affected sustainable rural development in reducing environmental effects. According to the people opinion, all the eight indices are at a significant level and were certainly effective on the sustainable development of rural areas. This fact is shown by the significance level $(\mathrm{Sig}=0.000)$ which is less $(.000<0.05)$. Moreover, based on the averages, tourism index with an average of 4.35 is the priority for rural development and the second priority is farming with an average 4.22 (Table 7).

\section{Conclusion}

Economically and socially, Karun 3 Dam had been different positive and negative effects on the surrounding villages. The obtained results indicated that the dam construction was affective in agricultural growth due to the existence of Dam Lake. In the same way, as agriculture has been the main part of the rural economy in the region, the dam has also been effective in strengthening the local economy by providing infrastructures for agriculture. On the contrary, the dam has not affected industrial and tourism development. Whereas they are expected due to the natural and spatial changes, Tourism and Industry should be improved. Also, this is true for employment, and there has been no change in the status of jobs, directly and indirectly, related to the dam. In addition, with comparing of the significant level of economic indices in the main group with 


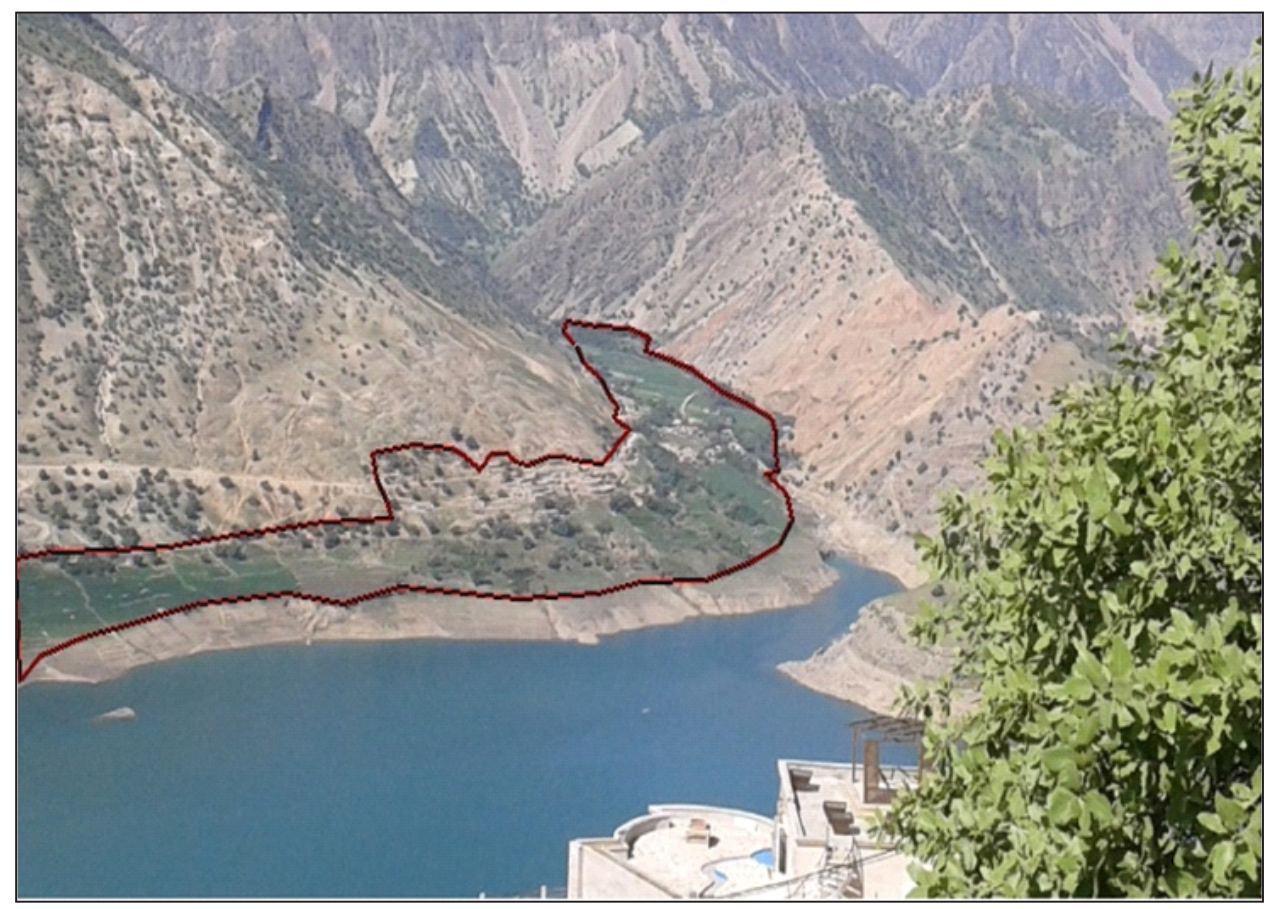

Photo 1. Sample surrounded village resulting from Karun 3 dam watering(2016)

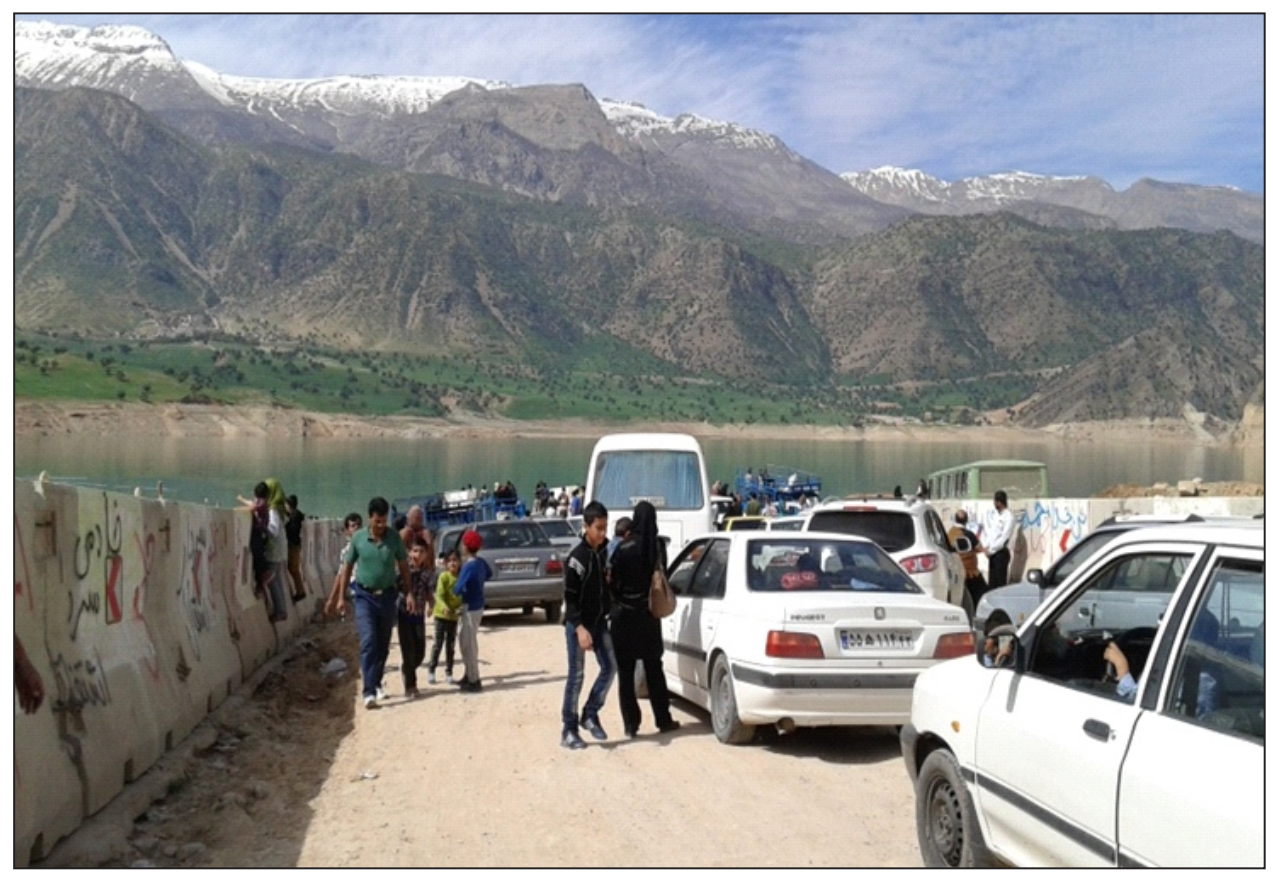

Photo 2. Transportation problems due to dam construction (2016) 


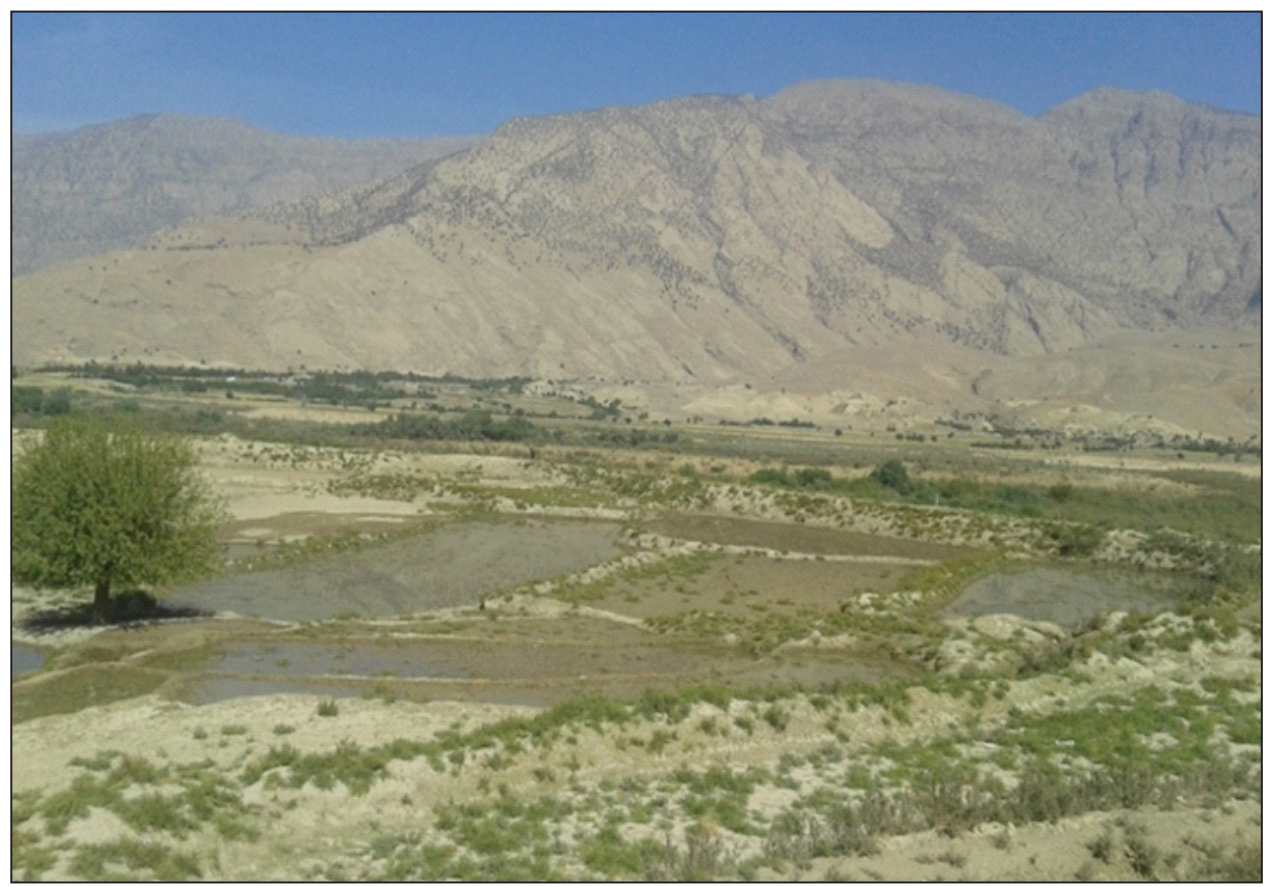

Photo 3. Dried land in the downstream the dam (2016)

the control group confirmed the effectiveness these indices and their changes due to the dam construction. In fact, these changes are related to the dam construction for all economic indices, including agricultural development in two periods. The dam also had not affected on the social capital, social welfare and quality of life, which needs consideration. Because, the dam can be useful in the social part with respect to its double-sided effects, but this point cannot be deduced from the results. The undesirable performance of the dam in the rural economy has been effective in this situation. Because, there is a significant relationship between the social capital, social welfare and quality of life with Economy. Therefore, when the dam has not had much effect on the improvement of economic indices, Social indices are undesirable too. In fact, there is no positive change in the improvement of these variables with the dam construction. It can be concluded that the status these indices were better before the dam construction. With comparing of the significant level of social indices in the main group with the control group confirmed the effectiveness these indices and their changes due to the dam construction.

In response to the question two of this article, it should be expressed that there existed a significant difference among the three types of rural areas as to socio-economic indices. This difference in the effectiveness of each one of indices was different for one of the rural areas. Only, there is no significant difference in agricultural development for three types of rural areas. In fact, agricultural development among three types of rural areas has not been different with respect to the dam construction.

As to the question three of this article, in accordance with prioritisation of obtained potentials, made available to through dam construction with the 
objective, sustainable development, tourism is the optimal choice, but the results indicated that the dam construction has not affected to improve it. The cut-off of rural roads (Photo 1), lack of services, waterborne transportation problems (Photo 2), reduced inhabitants of many rural areas, reduced tourism attractions of Karun River downstream of the dam caused by dehydration, lack of advertising concerning dam tourism development, and reduction in downstream farming (Photo 3) were the most important reasons that caused this status. However, overall tourism development is possible. Therefore, concerning the rural tourism capabilities of the region before dam construction and those added after it, more administrative attention and appropriate plans must be put on the agenda. Also, agriculture is the second priority for rural development with respect to the dam construction.

The important general point that can be deduced from the results this research is a duality in optimal management and based on sustainable development. In fact, from the beginning of the dam construction to its end (here Karun 3 dam), there is no detailed study that can strengthen and developed the surrounding rural areas as to a systematic process and based on sustainability principle. Therefore, the important point between the dam construction and surrounding villages, especially in developing countries for sustainable development, is lack of a systematic approach, which is considered development and development projects as a one-dimensional. In fact, lack of these factors caused that the Karun 3 dam has not had considerable effects on surrounding villages concerning economic and social variables.

\section{Acknowledgements}

This research was supported by the Department of Geography and Rural Planning, University of Isfahan, Iran. We express our gratitude towards the members of this department for their kind cooperation. Our appreciation also goes to Iran's Water Resources Development Company, Statistical Center, Agriculture Jihad Center, as well as the Rural Development Centers, who assisted us in gaining information and having access to the villages under study.

\section{References}

Bhatia, R., Cestti, R., Scatasta, M. and Malik, R. (2008), Indirect economic impacts of dams: case studies from India, Egypt, and Brazil, Washington, World Bank.

Campbell-Hyde, B. (2013), Breaking Ground: Environmental and Social Issues of the Three Gorges Dam in China, 24 may 2016, https://goo.gl/5M2iuG.

Huiyi, C. (2013), Sustainable Development in China's Decision Making on Large Dams: A case study of the Nu River Basin, Sweden, Uppsala University press.

Cuciureanu, M.S. and Latu, C. (2016), 'Socio-economic typologies of rural spaces in Moldavia region. Study case: Botosani County, Romania', Human Geograpghies Journal of Studies and Research in Human Geography, vol. 10, no. 1, pp.147-159.

DeVos, J.A., Van Bakel, P.J.T., Hoving, L.E. and Conijn, J.G. (2006), 'Waterpas- 
model: a predictive tool for water management, agriculture, and environment', Agricultural Water Management, vol. 86, no.1, pp.187-195.

Duflo, E. and Pande, R. (2007), 'Dams', Quarterly Journal of Economics, vol. 122, no. 2, pp. 601-646.

Egre, D. and Senecal, P. (2003), 'Social impact assessments of large dams throughout the world: lessons learned over two decades', Impact Assessment and Project Appraisal, vol. 21, no. 3, pp. 215-224.

Ghiami, A. (2011), The review of impacts of Tabarak Dam of Ghochan on the agricultural economy of rural households of central district (case Study: Shirin Dareh villiage), Mashhad, Ferdowsi University press.

Ishida, S., Kotoku, M., Abe, E., Fazal, M.A., Tesuchihara, T. and Imaizumi, M. (2003), 'Construction of Subsurface Dams and their Impact on the Environment', Journal of Material and Geoenvironment, vol. 50, no. 1, pp. 149152.

IWPCO (2012), The introduction of projects of Iran Water and Power Resources Development Company, Tehran, IWPCO press.

Jehad, T. (2002), The Plan studies the social, economic and natural basin upstream dam 3, Tehran, The organization Executive and Research university of Tehran press.

Kirchherr, J., Pohlner, H. and Charles, K. (2016), 'Cleaning up the big muddy: A meta-synthesis of the research on the social impact of dams', Environmental Impact Assessment Review, vol. 60, no. 1, pp.115-125.

Kirchherr, J. and Charles, K. (2016), 'The social impacts of dams: A new framework for scholarly analysis', Environmental Impact Assessment Review, vol. 60, no. 1, pp. 99-114.

Malekhoseini, A. and Mirakzedeh, A.A. (2014), 'Assessment of social impacts of Sonqure's Soleimanshah dam on the regions that are under influence of irrigation and drainage network of dam', Journal of Rural Research, vol. 5, no. 3, pp. 589-610.

Mikaniki, J. and Sadeghi, H. (2013), 'Determining the optimal spatial pattern of rural service centers by AHP method with an approach to land suitability (case study: Dehdiz District, Izeh County', Journal of Research and Rural Planning, vol. 1, no. 2, pp. 49-67.

Pirestani, M.R. and Shafaghati, M. (2009), 'Investigation of Environmental Impacts of Dam', Quarterly Journal of Human Geography, vol. 1, no. 3, pp. 39-50.

Qu, Y., Li, M., \& Qin, L. (2015), 'Environmental practice and its effect on the sustainable development of eco-industrial parks in China', International Journal of Sustainable Development and Planning, vol. 10, no. 5, pp. 685-700.

Rahmati, A. (2012), 'Evaluation of environmental impact assessment process in Iran Challenges and Solutions', Environment and Development Journal, vol. 5, no. 2, pp. 15-23.

Rahmati, A.R. and Nazareian, A. (2011), 'Socio-economic and environmental impact of the resident area inforce to move due to dams construction: case study dam, S Gotvand olia on the river of Karun', Journal of Environmental Researches, vol. 1, no. 2, pp. 53-66.

Riahi, M., Torabi, E. and Kabiri, A. (2013), 'Evaluating the environmental impacts of construction of dam on the Karun River in Chaharmahal and Bakhtiari Province', (paper delivered to the First National Conference of 
Hydrocylinders Power in Iran), Tehran, 27-28 May.

Sahdati, N., Maddinia, M. and Porvais, Sh. (2009), 'The review of environmental impacts of Marun dam in Behbahan', (The second Conference of water, Islamic Azad University of Behbahan), Behbahan.

Scudder, T. (2012), The Future of Large Dams, London, Earthscan press.

Shayan, H., Javan, J. and Kadivar, A. (2010), 'Analyzing the Social, economical and environmental consequences of Kerdeh Dam in Mashhad and Bedvaz Dam in Esferayen', Journal of Geography and Regional Development, vol. 7, no. 13, pp. 19-43.

Statistical Center of Iran (2006), Population and housing census 2006, Tehran, Statistical Center of Iran press.

Statistical Center of Iran (2011), Population and housing census 2011, Tehran, Statistical Center of Iran press.

Strobl, E. and Strobl, O.R. (2011), 'The Distributional impact of large Dams: Evidence from Cropland Productivity in Africa', Journal of Development Economics, vol. 96. no. 2, pp. 432-450.

Strzepek, K.M., Yohe, G.W., Tol, S.J.R. and Rosegrant, M.W. (2008), 'The value of the high Aswan Dam to the Egyptian economy', Journal of Ecological Economics, vol. 66, no. 1, pp.117-126.

Tahmicooglu, M.S., Anul, N., Ekmekci, F. and Durmus, N. (2007), Positive and negative impacts of dams on the environment, International Congress on River Basin Management, Turkey, pp. 759-769

Tilt, B., Braun, Y. and He, D. (2009), 'Social impacts of large dam projects: A comparison of international case studies and implications for best practice', Journal of Environmental Management, vol. 90, no. 3, pp.249-257.

WCD, World Commission on Dams (2000), Pak Mun Dam Case Study, TDRI Report for The world Commission on Dams, USA.

WCD, World Commission on Dams (2000), Dams and Development: A New Framework for Decision-making, London and Sterling, Earthscan Publications Ltd. 